\title{
THE INTERNET ADDICTION AS A PROBLEM IN SCHOOL AGE CHILDREN
}

\section{ZAVISNOST OD INTERNETA KAO PROBLEM ŠKOLSKE DECE}

Radoje Jevtić ${ }^{1}$, Dragana Jevtić

\section{SUMMARY}

During the past several years, the use of Internet has become a daily part of life for many people worldwide for many reasons. The development of new devices, the low cost of Internet services, and the great capabilities of the Internet, make Internet alluring for many adults and children to use it for many hours almost daily. However, there are some negative consequences of the Internet, especially for school-age children. One of these consequences is the so-called "Internet addiction". Many studies indicate that the Internet is becoming the primary and only means of communication, the principal and the sole medium when it comes to the life of a school-age child. There is a neglect of sports activities, socializing, live chat, going out in nature etc. Some aspects of the life are slowly being replaced by the virtual. The happiness that a child should feel when solving problems or during sport competitions, is being substituted by the happiness experienced while playing video games. The main responsibility lies within the family and school teachers, who must jointly and constantly supervise and direct children to other aspects of life, nature, socializing, sports etc. Of course, the use of the Internet should not be criticized or disputed, and it should be viewed as something that makes life easier and intends to serve the users. This review summarizes the results of previous research on the misuse of the Internet by school-age children in different countries of the world and at the Electrotechnical school "Nikola Tesla" in Niš, with the aim of proposing appropriate preventive measures to ensure their proper development and guidance.

Keywords: internet, addiction, research, secondary school

\section{Introduction}

Generally, the Internet represents a world system of computer-integrated networks that changed the way communication systems were functioning. The history of Internet was connected with founding of Advanced Research Projects Agency Network (ARPANET) in 1969, the computer network controlled by the Ministry of defense of the

\section{SAŽETAK}

Tokom prethodnih nekoliko godina, internet je postao svakodnevni deo života za mnoge ljude širom sveta. Razvoj različitih uređaja, niska cena internet usluga i velike mogućnosti interneta omogućavaju da veliki broj ljudi i dece koristi internet više sati, gotovo svakodnevno. Međutim, postoje i neke negativne posledice interneta, posebno kod školske dece. Jedna od tih posledica je, tzv. „zavisnost od interneta“. Mnoga istraživanja ukazuju da internet postaje glavno i jedino sredstvo komunikacije i glavni i jedini medijum kada je u pitanju život deteta školskog uzrasta. Dolazi do zanemarivanja sportskih aktivnosti, druženja, živog razgovora, odlaska u prirodu i sl. Određeni aspekti svakodnevnog života se polako zamenjuju virtuelnim. Sreća koju dete treba da oseti prilikom rešavanja problema ili prilikom sportskih takmičenja se zamenjuje srećom koju dete oseća dok igra video igre. Glavna odgovornost leži u porodici i nastavnicima koji moraju udruženo i stalno kontrolisati i usmeravati decu na realan život, na prirodu, druženje, sport i sl. Naravno, pri tome ne treba kritikovati niti osporavati upotrebu interneta, ali treba stalno podsećati da je internet tu da nam olakša život i da služi korisnicima, a ne da korisnici služe njemu. U ovom preglednom radu prikazani su rezultati dosadašnjih istraživanja o zloupotrebi interneta od strane školske dece kako u različitim zemljama sveta, tako i u Elektrotehničkoj školi "Nikola Tesla" u Nišu, sa ciljem predlaganja odgovarajućih preventivnih mera radi obezbeđivanja njihovog pravilnog razvijanja i usmeravanja.

Ključne reči: internet, zavisnost, škola, deca

United States (1). Today, the Internet connects billions of computers all around the world in one non-hierarchical way. Also, today the Internet represents technical innovation that transforms society, economy and many other aspects of human activities and interests. From the beginning, the Internet has been characterized by its permanent expansion, related to the growing number of users and information becoming available to them. At first, the Internet

${ }^{1}$ Elektotehnička škola „Nikola Tesla“ (Electrotechnical school “Nikola Tesla”) 
was available only via computers; today, there are many devices which can be connected to the Internet, such as laptops, tablets and smart mobile phones. There are many services on the Internet that are used for different purposes, such as WWW-World Wide Web (transfer of web pages written in HTML), Chat (written communication), Skype (direct visual and voice communication), e-mail, Usenet and many others.

\section{Investigations of the Internet addiction worldwide}

On the global level, according to the latest statistics reports, until the June 2019, there was 4.422.494.622 Internet users. The overview is the following: Asia - $49.8 \%$, Europe - 16.3\%, Africa - 11.9\%, Latin America/Caribs - 10.1\%, North America - 7.4\%, Middle East - 3.9\% and Oceania/ Australia $-0.6 \%$ (2). The lowest number of Internet users is in Africa, in Chad (2.7\%), Nigeria $(2.2 \%)$, Somalia $(1.8 \%)$ and Eritrea (1.1\%). In 2018, the highest number of mobile subscribers per 100 people was in Hong Kong (259.4) and the lowest in the Central African Republic (27.7) (3). Worldwide, the average was 110.3 subscribers per 100 people (3).

Great changes in the modern world were caused by the occurrence of social nets on the Internet. Social networks are different free online services that provide their users with different ways of communications with people all around the world and have a great potential of self-presentation (via pictures, video contents, blogs and similar). From the beginning of the 21 st century, a number of social networks appeared, most famous being Facebook, Twitter, LinkedIn, etc. It is obvious that the Internet has great benefits related to human interests and activities, but also, it was noted that the Internet has become more than information - communication instrument for a great number of users, and unfortunately the object of pathological addiction and compulsive need (4).

One of the mostrecentand frequentlyused terms in the negative sense about the Internet is so-called "Internet addiction". The Internet addiction is a psychophysic disturbance that implies tolerance - the occurrence that user spends more and more time on the Internet for the purpose of achieving the same quantity of pleasure; after that, it implies the symptoms of social retreat (overstrain, anxiety, grudge and similar when person doesn't use the Internet); affective disturbances (depression and irritability) and damaged social relations (the loss of quality and quantity of the relationship with surroundings) (5). The same author compares the given definition with the present definition of addiction which is applied and related to alcoholism and drug addiction as the most frequent forms of addiction. The author noted that there are no differences between these forms of addictions, except in the fact that there is no physical import of destructive substance in organism in the case of the Internet. Regarding the last fact, one part of the science publicity asks the question of how it is possible to use the term addiction (5).

The Internet, in the current form, presents the main communication medium and source of information in the modern world. People, especially young people, spend more and more time in front of the screens of their laptops, computers and mobile phones. In the situation where virtual life replaces real life, the question about reasons for overuse of the Internet is being raised. One of the presumptions is that such behavior is based on the certain psychical difficulties of personal, familial or professional nature. The exploration of the relationship between the time that young people spend on the Internet and social networks and feeling of the seclusion showed that pupils spend three hours on average on a daily basis, where boys spend significantly more time on the Internet than girls and their feeling of seclusion was more evident. It has been shown that there is a significant relationship between time spent on the Internet and social networks and the feeling of seclusion. Also higher level of emotional seclusion, lower level of selfrespect and lower level of social skills related to medium Internet users was noted (6).

Along with the increased usage of the Internet, the number of researches about its influence on social relationships, life habits and personality of its users also increased $(7,8)$. It is very important to note that many contradictions could be found in those researches, so, according to that, some of them accent the positive influence of the Internet on greater social activities, identity development, while some of them point out the superficial relationships with users, social isolation, depression and similar $(9,10)$.

One of the first serious researches in the field of Internet addiction was the research by the author Kimberly Young. She determined, apart from the significance of the problem of the Internet addiction, models of Internet usage for addicted users so as potential ways of adequate problem treatment. Those 
researches showed that addicted Internet users spent eight times more time on the Internet than users from the control group, so that they suffered consequences in the field of social relationships, professional work, academic skills adoption, which all had financial consequences beside physical consequences (11). Using the criteria from the fourth edition of diagnostic and statistical manual DSM-IV for pathological gambling (gambling is considered as the most similar form of addiction to Internet addiction), Young developed the test for Internet addiction detection in 2004 (IAT- Internet addiction test) (12). In order for a person to be recognised as Internet addict, five or more criteria out of eight noted should be fulfilled within the time period of six months:

- occupation by the object of addiction;

- tolerance on Internet usage (decreased satisfaction by time spent on the Internet, the need for constant time increment on the Internet);

- the appearance of abstention crisis at the attempt of usage decrement or prohibiting the Internet (anxiousness, slough, irritability);

- impossibility to control of the Internet usage (ineffectual attempts to forbid or interrupt Internet usage);

- the time spent on the Internet is much longer than planned time;

- the hiding of the real time spent on the Internet (fooling the family, colleges, doctors, therapeutics and similar) and

- perception of the Internet as a way to escape from problems (12).

There are several types of Internet addiction, but one of the most popular and the most famous has arisen as result of practical work of 35 psychologists with dependent patients (11). The great number of certain activities and compulsive behaviors were classified and assorted in the following five types:

- cyber-sexual addiction (the usage of web sites for cyber-sex and cyber pornography), where addicted population succeeded to preserve their behavior at the sexual phantasy level. It is important to note that this kind of Internet addicts is different from classic sexual delinquents because they use the Internet only as a way of escaping from problems in real life;

- social network addiction (Facebook, Twitter, LinkedIn and similar);

- net compulsions (gamble addiction, purchasing and playing video games online). This addiction type makes is exception by some authors because, for example, gambling occurs under the influence of certain factors, while the rest are connected with the Internet (compulsive gambling behavior can be performed without Internet) (12);

- the glut of information (obsessive surfing and searching through databases either for professional interests or fun, but without interactions) and

- addiction to information communication technologies (computers, mobile phones, tablets and similar) $(4,12-14)$.

The great number of studies on pathological Internet usage showed that a number of users increases and that it's gaining very serious proportions. It is probably enough to note that hither researches showed that between 5 and $10 \%$ of user population show maladaptive forms of Internet misuse. Researches accentuate that Internet addicts spend between 40 and 80 hours per week on the Internet, sometimes more than 20 hours continually. In order to adapt to this state, their sleeping rhythm was very disturbed. This kind of rest and sleep period disturbance leads to sensations of chronic weariness, immune system collapse, appetite disorder, frequent headaches, profuse coffee consumption, which all together significantly increase organism vulnerability and makes it prone to many diseases (5).

Related to digital technologies addiction, it is important to mention the prevalence of the number of addicted teenagers in relation to complete teenagers number. In one great research which was realized in 2014, in several Asian countries (Japan, China, South Korea, Malaysia and the Philippines), the prevalence of internet behavior and addiction was examined. The complete prevalence of addicted teenagers regarding smart mobile phones usage was $62 \%$, ranging from $41 \%$ (China) to $4 \%$ (South Korea); participation in on-line games ranged from $11 \%$ (China) to $39 \%$ (Japan). The Internet addiction is usual among the adolescents in Asian countries so the problematic usage of the Internet also characterizes problematic cyber behavior of the young in those countries. The prevalence of the addiction from the Internet among teenagers was from $13-46 \%$. It is very high and it is connected to high development and technical performances in those countries (15). Highly expressed depression symptoms and social isolation could be noted in children that spent too much time on Internet. 


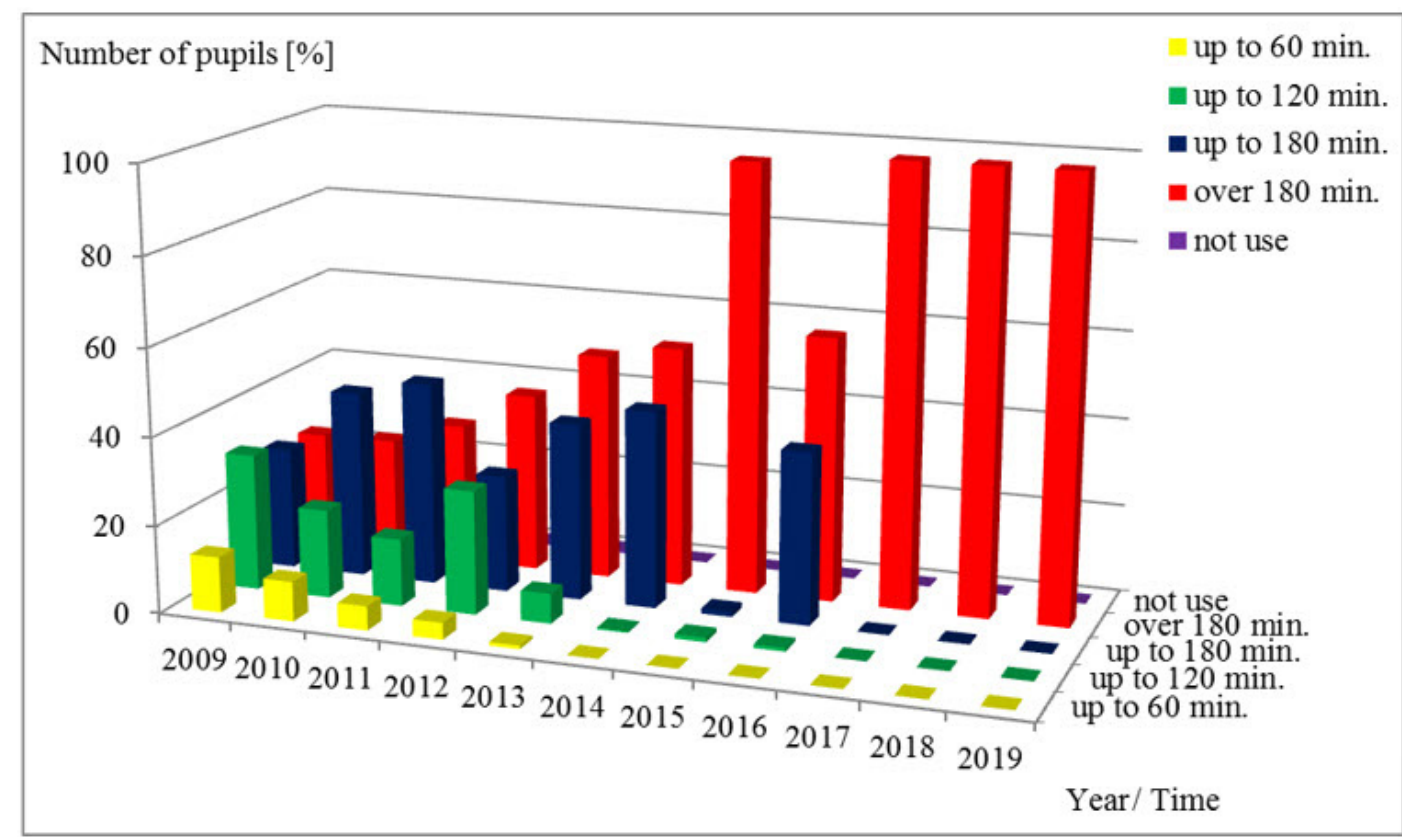

Figure 1. The average daily usage of the Internet by pupils in Electrotechnical school "Nikola Tesla" from 2009 to 2019

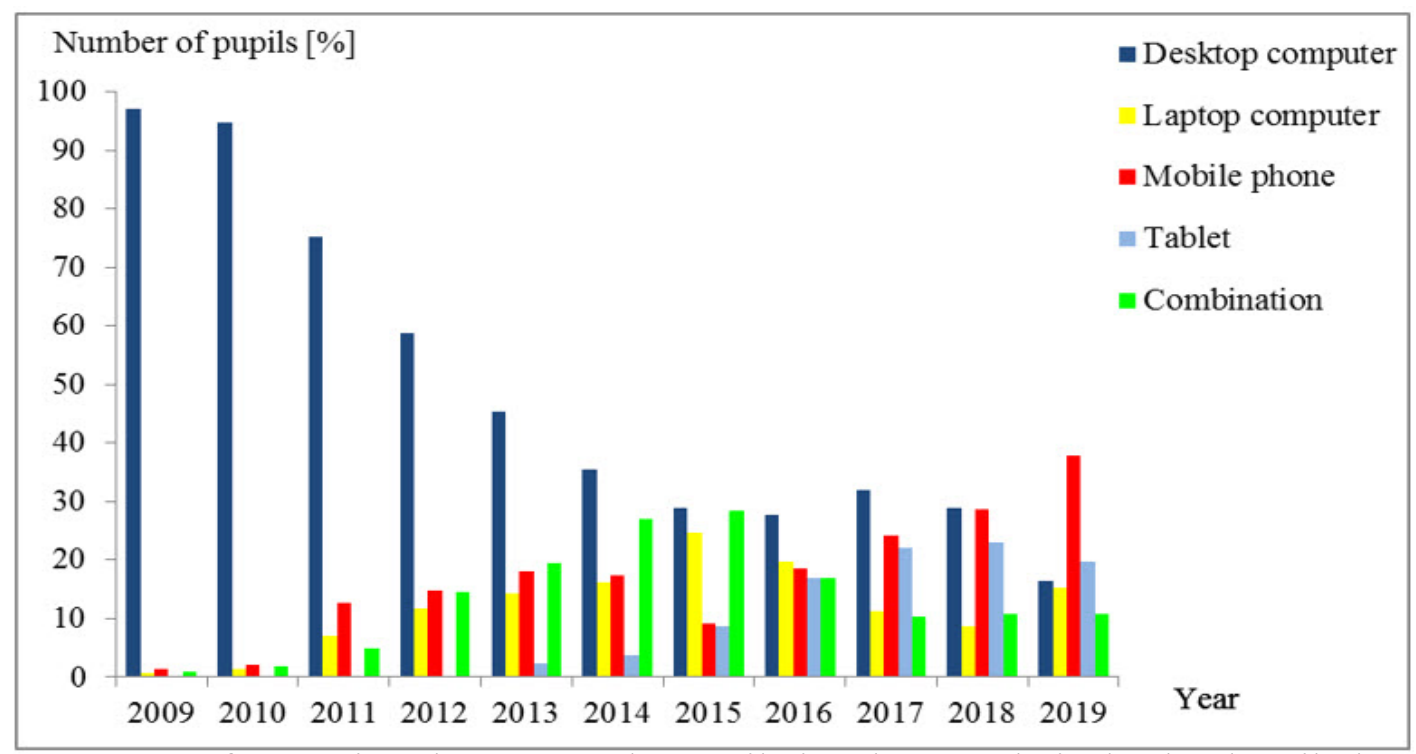

Figure 2. Ways of accessing the Internet by pupils in Electrotechnical school "Nikola Tesla" from 2009 to 2019

\section{Investigations of the Internet addiction in Niš, Serbia}

In our county, the studies were conducted in Niš, in Electrotechnical school "Nikola Tesla", in the period between 2009 and 2019. The investigations were related to, in the first place, mobile phones, their usage, their electromagnetic radiation (electric and magnetic field). After that, investigations were expanded on laptop usage, computers usage, Internet usage, and Facebook usage. In different periods of time different number of pupils were included (500 pupils for each year from 2013 till
2015 and from 2017 till 2019, and 600 pupils for each year from 2009 till 2012 and in 2016) $(4,13,14,16-20)$. Total number of included pupils was 6000 . All data from the pupils were collected by the means of questionnaire. The questionnaire consisted of questions about the average time spent on the Internet, purpose of Internet usage, ways of accessing to the Internet, help that the Internet provides in real life and learning, visiting some inappropriate contents (sites with porn contents, violence etc.), changing real life with virtual and many others. The most important results from all of these studies are presented on figures. 


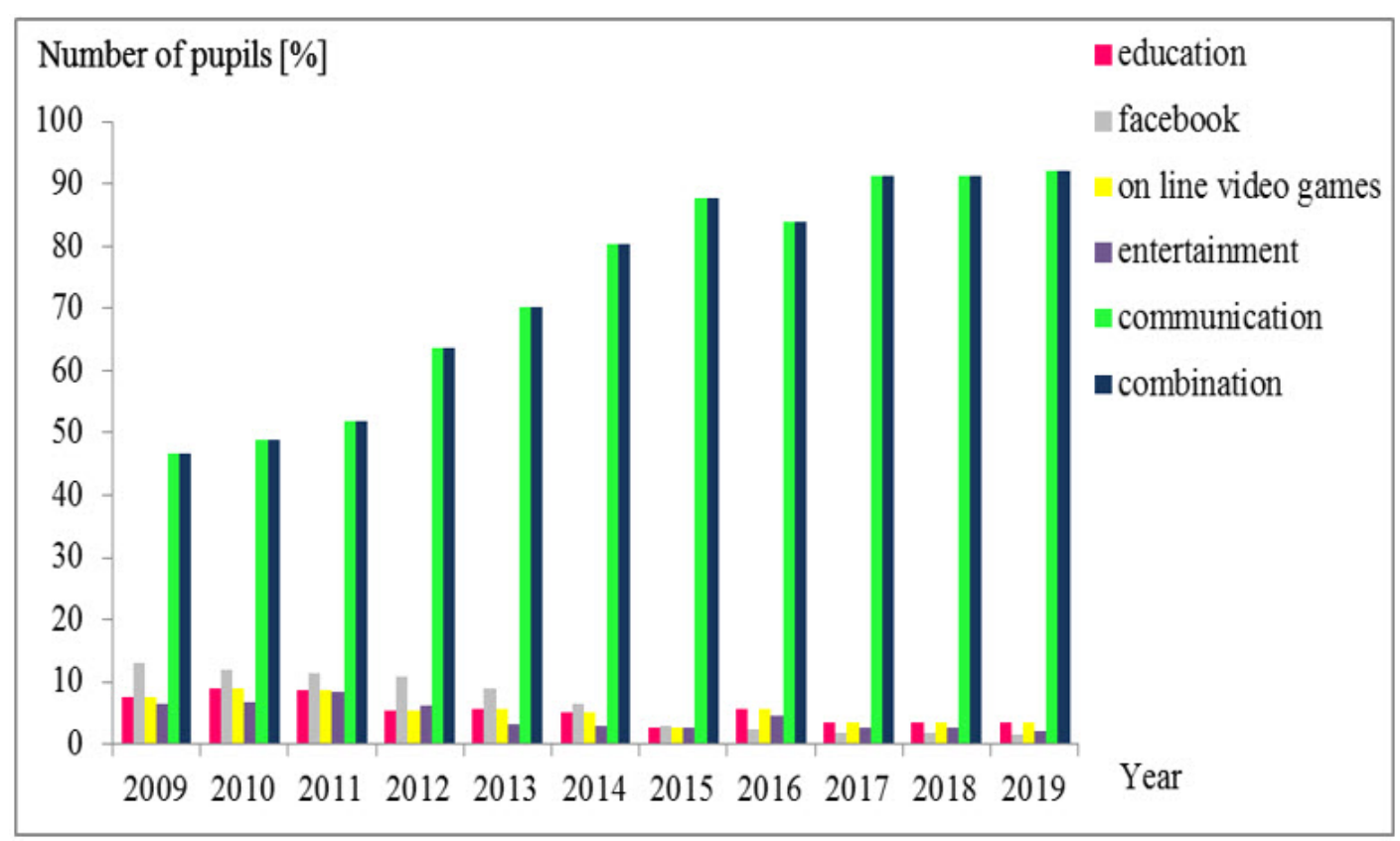

Figure 3. The purpose of Internet usage by pupils in Electrotechnical school "Nikola Tesla" from 2009 to 2019

Average daily usage of the Internet increased in the last several years (Figure 1), which was expected. In particular, the percentage of those who have been online for more than 3 hours a day has increased during the last five years (fourth red painted column in Figure 1). Also all pupils used Internet between 2009 and 2019 (fifth purple painted column on Figure 1). School-age children today have great possibilities on the Internet such as learning, electronic books, history contents, fun and many others. However, that fact does not imply that other resources and activities, such as books, sports, walking, fishing, theatre, cinema and many others should be ignored. The main device for Internet access during the first several years was a desktop computer, but in 2019 it was mobile telephone (Figure 2). But laptops and tablets are also very popular for Internet access over the last few years. Today, the Internet is available, especially wireless Internet so Internet users don't have to be physically connected to the Internet. Also, the low price of laptops, smart phones and tablets enabled to their users to provide and use them. Throughout the period, the highest number of pupils in Electrotechnical school "Nikola Tesla" used the Internet for communication, but the lowest used it for learning (Figure 3). That's surprising because all respondents were pupils. Results presented on Figure 4 maybe the best way to explain the term "Internet addiction". In the period during which the research was conducted, the percentage of school-age children that couldn't imagine their lives without the Internet was always bigger than $95 \%$ of all examined. Also, there are more and more school-age children that visit some Internet site with inappropriate contents (Figure 5). This is particularly troubling because the appearance of violence between school-age children in the recent period rapidly increases and can have very serious consequences, even with death scenario. Easy access to different inappropriate contents at one emotionally and socially unformed young person without proper and strict school and family control could create different dangerous, violent and destructive ideas.

The Internet and other mediums are present in all life segments and they are component parts of modern society. As a "public opinion" creator, the Internet as one massive medium can form models of children's behaviors. The researched literature showed that the knowledge about the etiology of "Internet addiction" is still insufficient. It is obvious that there is not only one cause of the addiction. In modern society, the greater influence of massive communication mediums can be noticed, so many researchers place it as one of the most important causes of socialization. One of the most important reasons of the decreasing influence of parents and school lies in the fact that the model of a digital picture is much richer in details, clearer, and more concrete, so, according to that, much easier to adopt than moralities and verbal instructions about proper behavior. 
Related to many modern theories, presentation in media is considered very important for identity forming. It is also important for the public perception of actors, it influences on social attitude related to minorities, including their acceptance or rejection. For this reason, the consequences of the inappropriate presentation are great and serious. The ways how children and young people absorb those influences are imitation, identification, learn- ing by model and inspiration (21). The addiction is a process that implies different phases and answers on treatment and largely depends on individual factors. One of the main indicators of addiction is that the person does not accept the fact that its behavior is out of control and denies that the problem exists (22). Denial is psychological and defensive mechanism that enables a person to continue their maladaptive behavior that obviously has bad

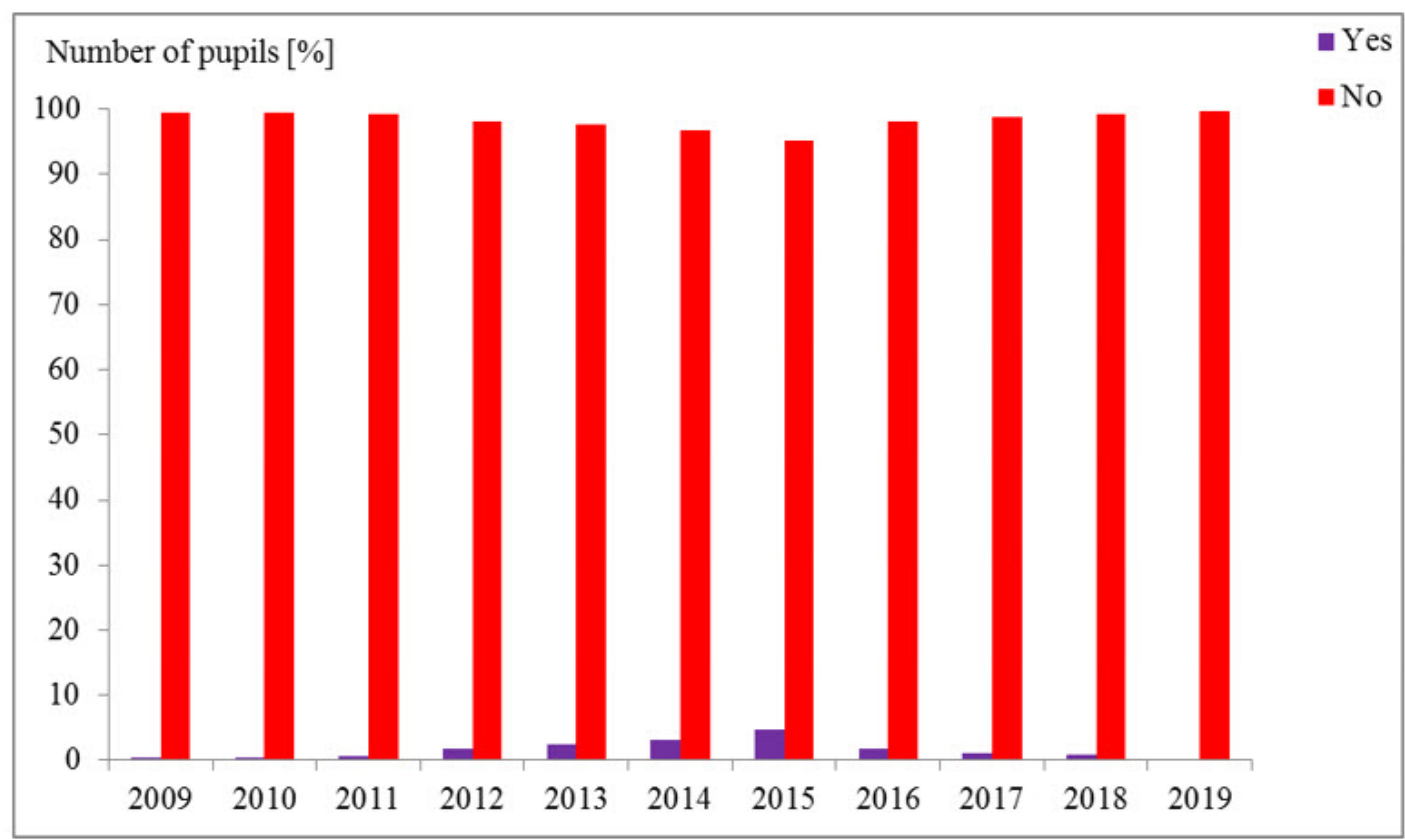

Figure 4. Percentage of pupils from Electrotechnical school "Nikola Tesla" that could not imagine their life without Internet/Facebook usage, 2009-2019

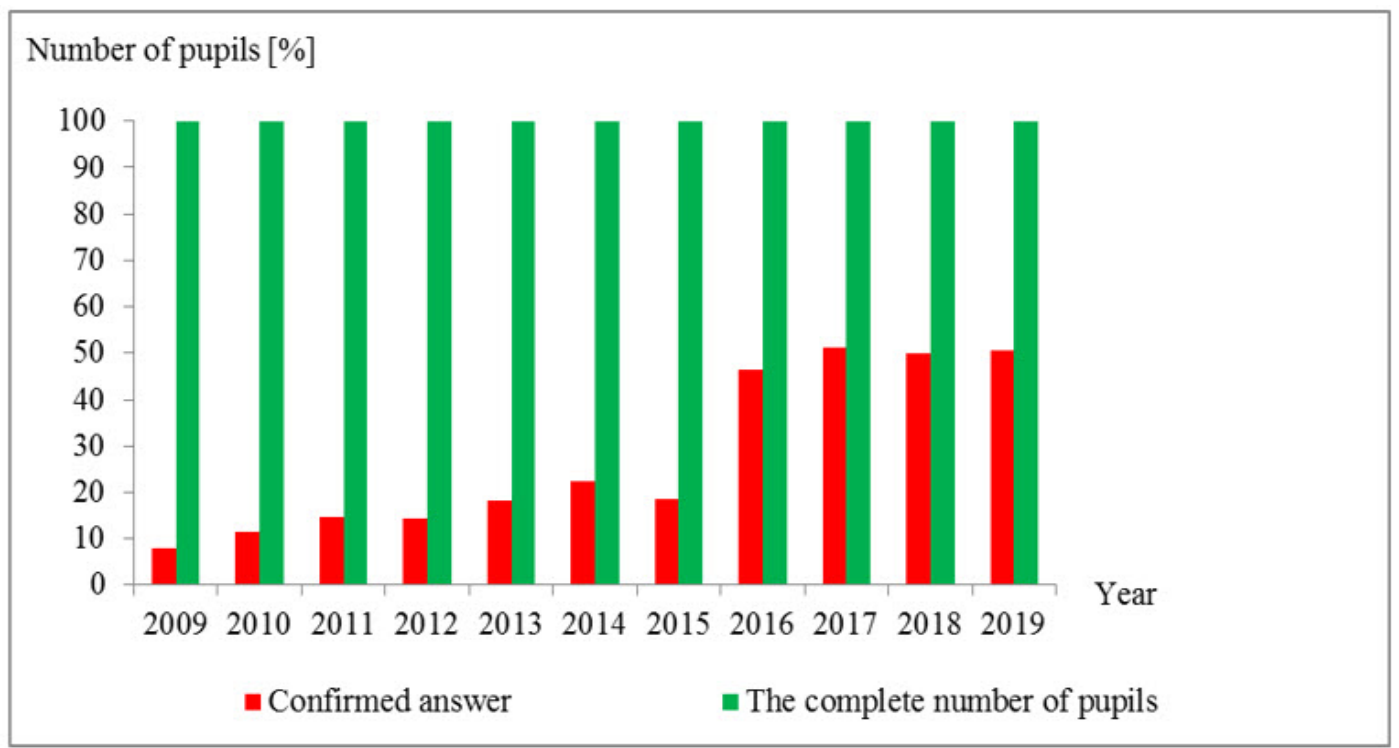

Figure 5. Percentage of pupils from Electrotechnical school "Nikola Tesla" that visited some site with inappropriate content (porn sites, sites with violence contents and similar), 2009-2019 
influence on individual`s quality of life $(5,23)$. Conclusions

The main problem in the population of school age children is finding the balance between smart and purposeful Internet usage and Internet usage that becomes an addiction. Crucial role here lies with family members and teachers. They have to join forces in order to supervise and direct children to sport, social and nature activities, continually explaining that the Internet presents medium created to serve people, not the other way around.

\section{References}

1. Naughton J. The evolution of the Internet: from military experiment to General Purpose Technology. Journal of Cyber Policy 2016; 1(1):5-28.

2. Internet World Stats. Available at: https://www. internetworldstats.com /stats.htm

3. TheGlobalEconomy.com. Available at: https:// www.theglobaleconomy.com/rankings/Mobile_phone subscribers per 100 people/.

4. Jevtić BR, Jevtić DD, Ničković TJ, Ničković SV. Internet and Facebook-modern problems of school age children. Tehnika elektrotehnika 2012; 4: 602-6.

5. Bugarski Ignjatović V. Zavisnost od internetaput ka novoj dijagnostičkoj kategoriji. Aktuelnosti iz neurologije, psihijatrije i graničnih područja 2003; XI (2):50-6.

6. Ačkovska Leškovska E. Internet, društvene mreže i osećaj usamljenosti kod učenika. II Kongres psihologa Bosne i Hercegovine, Društva psihologi Republike Srpske i Društva psihologa u Federaciji Bosne i Hercegovine. Knjiga rezimea. Banja Luka, 24-26. februara 2011: 39

7. Chen X, Pan Y, Guo B. The influence of personality traits and social networks on the self-disclosure behavior of social network site users. Internet Research 2016;26(3):566-586. DOI: 10.1108/IntR-05-20140145 .

8. Ioannidis $\mathrm{K}$, Hook R, Goudriaan AE, Vlies S, Fineberg NA, Grant JE, Chamberlain SR. Cognitive deficits in problematic internet use: meta-analysis of 40 studies. Br J Psychiatry 2019;1-8. doi: 10.1192/ bjp.2019.3. [Epub ahead of print]

9. Kraut R, Patterson M, Lundmark V, Kiesler S, Mukopadhyay T and Scherlis W. Internet paradox: a social technology at reduces social involvement and psychological well-being? Am Psychol 1998;53 (9):1017-
31.

10. Nie N, Erbring L. Internet and mass media: a preliminary report. It\&Society 2002;1 (2):134-41.

11. Young K, Pistner M, O’Mara J, Buchanan J. Cyber disorders: the mental health concern for the new millennium. Cyberpsychol Behav 2000; 3(5):475-9.

12. Kovačević-Lepojević M. Pojam i karakteristike internet zavisnosti. Specijalna edukacija i rehabilitacija 2011; 10(4):615-31

13. Jevtić BR, Jevtić DD. Uticaj modernih tehnologija na život i rad školske dece. Učenje i nastava 2015; 2:383-98.

14. Jevtić BR, Jevtić DD, Ničković TJ, Ničković SV. Termički efekti mobilnih telefona-nova merenja. Zdravstvena zaštita 2015; XLIV (3):39-47.

15. Kwok-Kei M, Ching-Man L, Hiroko W, Dong K, Bahar N, Ramos M, et al. Epidemiology of Internet Behaviours and Addiction Among Adolescents in Six Asian Countries. Cyberpsychol Behav Soc Netw 2014; 17(11):720-8.

16. Jevtić BR. Raspodela elektromagnetnog polja frekvencija mobilnih komunikacija u čoveku. Magistarska teza. Niš: Fakultet Zaštite na radu u Nišu, 2009.

17. Jevtić BR, Jevtić DD, Ničković TJ, Ničković SV. Zdravstveni aspekti tehničkog okruženja savremenog čoveka. Zdravstvena zaštita 2013; XLII (5):60-7.

18. Jevtić BR, Ničković TJ, Jevtić DD. SAR i termički efekti mobilnih telefona. Tehnika elektrotehnika 2011; 1:95-9.

19. Jevtić BR, Jevtić DD, Stoiljković ZJ. Internet and facebook - potential effects on school age children. Zdravstvena zaštita 2017; XLVI (2):73-9.

20. Jevtić DD, Ničković SV, Jevtić BR, Ničković TJ, Ničković V. Socijalni i zdravstveni problemi dece školskog uzrasta usled korišćenja Facebook-a. Učitelj 2012; 79(1): 34-42.

21. Huremović L. Izvan četiri zida. Priručnik za novinarke i novinare o profesionalnom i etičkom izvještavanju o LGBT temama. Sarajevo: Sarajevski otvoreni centar, 2012.

22. Egger O, Rauterberg M. Internet and addiction. Zurich: Swiss Federal Institute of Technology, 1996.

23. Anderson E, Steen E, Stavropoluos V. Internet use and Problematic Internet Use: a systematic review of longitudinal research trends in adolescence and emergent adulthood. Int J Adoles Youth 2016;22 (4): 1-25.

Conflict of interest: None declared.

Received (primljen): 06/19/2019

Revised (revizija): 09/18/2019

Accepted (prihvaćen): 09/20/2019

Online first: 09/30/2019

Kontakt: dr Radoje Jevtić, Elektotehnička škola „Nikola Tesla“, Aleksandra Medvedeva 18, 18000 Niš, Srbija; e-mail: milan.jvtc@gmail.com

Correspondence to: dr Radoje Jevtić, Electrotechnical school "Nikola Tesla", Aleksandra Medvedeva 18,18000 Niš, Serbia; e-mail:milan.jvtc@gmail.com 